\title{
The influenza $\mathrm{A}(\mathrm{H} 5 \mathrm{~N} 1)$ epidemic at six and a half years: 500 notified human cases and more to come
}

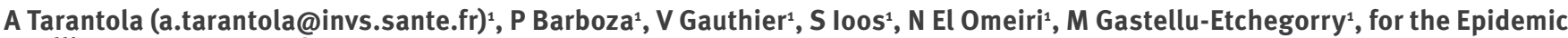
Intelligence team at InVS ${ }^{2}$

1. International and Tropical Department, Institut de Veille Sanitaire, Saint-Maurice, France

2. The members of the team are listed at the end of the article

Citation style for this article:

Tarantola A, Barboza P, Gauthier V, loos S, El Omeiri N, Gastellu-Etchegorry M, for the Epidemic Intelligence team at InVS. The influenza A(H5N1) epidemic at six and a half years: 500 notified human cases and more to come. Euro Surveill. 2010;15(29):pii=19619. Available online: http://www.eurosurveillance.org/ViewArticle.

aspx?Articleld=19619

Article published on 22 July 2010

Since November 2003, the epidemic intelligence team at the French Institut de Veille Sanitaire has been gathering data on influenza $\mathrm{A}\left(\mathrm{H}_{5} \mathrm{~N}_{1}\right)$ circulation in poultry and on human cases worldwide. As Indonesia notifies the world's 50oth case to the World Health Organization, we discuss the epidemiological situation and trends of $\mathrm{A}\left(\mathrm{H}_{5} \mathrm{~N}_{1}\right)$ influenza. Although the overall number of cases reported worldwide has decreased, influenza $\mathrm{A}\left(\mathrm{H}_{5} \mathrm{~N}_{1}\right)$ continues to circulate intensely in some countries and more cases are to be expected, especially in Egypt and Indonesia.

The international and tropical department of the Institut de Veille Sanitaire (InVS) conducts constant monitoring of health events worldwide to provide French health authorities with timely forewarning of public health events of international concern. This process, known as epidemic intelligence (EI), has been described elsewhere [1]. Although topics vary widely, the situation of highly pathogenic influenza $\mathrm{A}\left(\mathrm{H}_{5} \mathrm{~N}_{1}\right)$ influenza in the world has constantly been monitored since 2003. This paper describes the epidemiological situation six and a half years into the epidemic, as Indonesian authorities notify the world's 500th case since November 2003 [2].

\section{Epizootic}

From the end of 2003 to 1 July 2010, 63 countries or territories on the Asian, African or European continents (incl. 15 European Union countries) have notified infections by influenza $\mathrm{A}\left(\mathrm{H}_{5} \mathrm{~N}_{1}\right)$ virus in poultry or wild birds to the World Organization for Animal Health (OIE) [3]. In 2009, a total of nine countries notified outbreaks in poultry or were considered enzootic by OIE: Bangladesh, Cambodia, China (Tibet and Xinjiang), Egypt, India, Indonesia, Laos, Nepal (first notification) and Vietnam. Six other countries or territories notified cases in wild birds only: China (Qinghai and Hong Kong SAR), Germany, Mongolia and the Russian Federation (Moscow Oblast and Republic of Tyva). In 2010, twelve countries have been affected to date: Bangladesh, Bhutan (for the first time), Cambodia, Egypt, India, Indonesia, Israel, Laos, Myanmar, Nepal, Romania and Vietnam. Furthermore, in 2010, cases were reported in wild birds only by animal health authorities in Bulgaria, China (Tibet and Hong Kong SAR), Mongolia and the Russian Federation (Republic of Tyva). Many other countries, notably in sub-Saharan Africa, have suspected transmission in predominantly backyard flocks, but lack surveillance systems to document it. Table 1 summarises the circulation of the virus in animals in those countries with documented human cases, as assessed by the El team.

Since 2003 , cases of influenza $A\left(\mathrm{H}_{5} \mathrm{~N}_{1}\right)$ virus infection have also been occasionally documented in wild (felines, ferrets etc.) or domestic mammals (cats and dogs). No secondary transmission to humans, however, has been described following contacts with animals other than poultry or wild birds.

Wild aquatic fowl constitute the animal reservoir and have occasionally reintroduced influenza $A\left(\mathrm{H}_{5} \mathrm{~N}_{1}\right)$ - in European countries along the Danube or in Vietnam for example - leading to sporadic outbreaks in poultry flocks despite previous and successful elimination efforts.

\section{Human epidemic}

From 1 November 2003 to 1 July 2010 (by date of symptom onset), a total of 500 confirmed human cases of influenza $\mathrm{A}\left(\mathrm{H}_{5} \mathrm{~N}_{1}\right)$ including 296 deaths (case fatality rate (CFR) 59\%) were notified to the World Health Organization (WHO) by 15 countries [4] (Table 1 and Figure 1).

From 1 January to 1 July 2010, 32 confirmed human cases including 14 deaths (CFR 44\%) were notified by seven countries (Tables 1 and 2, Figure 2). During the same period in 2009, 41 confirmed human cases including 12 deaths (CFR 29\%) were notified by China, Egypt and Vietnam (Figure 1). Indonesia also reported 18 cases during that period, although data on deaths by date are not available. In 2009, a total of 73 confirmed human cases including 32 deaths (CFR 44\%) were notified by these four countries plus Cambodia (Table 1). Five countries, which had notified cases in preceding years, 
have notified no new cases since 2006: Azerbaijan, Djibouti, Iraq, Thailand and Turkey. Three additional countries (Laos, Myanmar and Pakistan) have not notified any case since 2007 .

Since November 2003, reported human cases seem to follow an overall downward trend and occur mostly during the period from November to April (Figure 1).
This variation is due to seasonal patterns described also in poultry $[5,6]$ in the countries which were mainly affected in the northern hemisphere, especially Egypt, Thailand and Vietnam. In Indonesia, however, cases tend to occur throughout the year.

Since the end of 2003 , most (366 of $500 ; 73 \%$ ) notified human cases of influenza $\mathrm{A}\left(\mathrm{H}_{5} \mathrm{~N}_{1}\right)$ occurred in

\section{TABLE 1}

Schematic representation of animal outbreaks (colour) and human cases (figures) in 15 countries which notified human cases to the World Health Organization, by date of onset, 1 November 2003- 1 July 2010 ( $n=500$ human cases)

\begin{tabular}{|c|c|c|c|c|c|c|c|}
\hline Country / Year & Nov 2003- Dec 2005 & 2006 & 2007 & 2008 & 2009 & To 1 July 2010 & Total \\
\hline Azerbaijan & 0 & 8 & 0 & 0 & 0 & 0 & 8 \\
\hline Bangladesh & 0 & 0 & 0 & 1 & 0 & 0 & 1 \\
\hline China & 9 & 13 & 5 & 4 & 7 & 1 & 39 \\
\hline Djibouti & 0 & 1 & 0 & 0 & 0 & 0 & 1 \\
\hline Egypt & 0 & 18 & 25 & 8 & 39 & 19 & 109 \\
\hline Indonesia & 20 & 55 & 42 & 24 & 21 & 4 & 166 \\
\hline Iraq & 0 & 3 & 0 & 0 & 0 & 0 & 3 \\
\hline Laos & 0 & 0 & 2 & 0 & 0 & 0 & 2 \\
\hline Myanmar & 0 & 0 & 1 & 0 & 0 & 0 & 1 \\
\hline Nigeria & 0 & 0 & 1 & 0 & 0 & 0 & 1 \\
\hline Pakistan & 0 & 0 & 3 & 0 & 0 & 0 & 3 \\
\hline Turkey & 0 & 12 & 0 & 0 & 0 & 0 & 12 \\
\hline Vietnam $^{a}$ & 93 & 0 & 8 & 6 & 5 & 7 & 119 \\
\hline Total & 148 & 115 & 88 & 44 & 73 & 32 & 500 \\
\hline
\end{tabular}

Light blue boxes: sporadic and/or seasonal outbreaks notified in poultry; grey boxes: poultry outbreaks reported throughout the year; white boxes: no avian outbreak reported.

With a high degree of seasonal and geographical variation.

Source: Data collected by the epidemic intelligence team at Institut de Veille Sanitaire from postings on the websites of the World Health Organization, the World Organization for Animal Health and other authoritative national sources in the 15 countries.

\section{FIGURE 1}

Notified cases of human influenza A(H5N1) virus infection in the world, 1 November 2003-1 July 2010, by month and date of symptom onset with moving average over two preceding months $(n=500)$

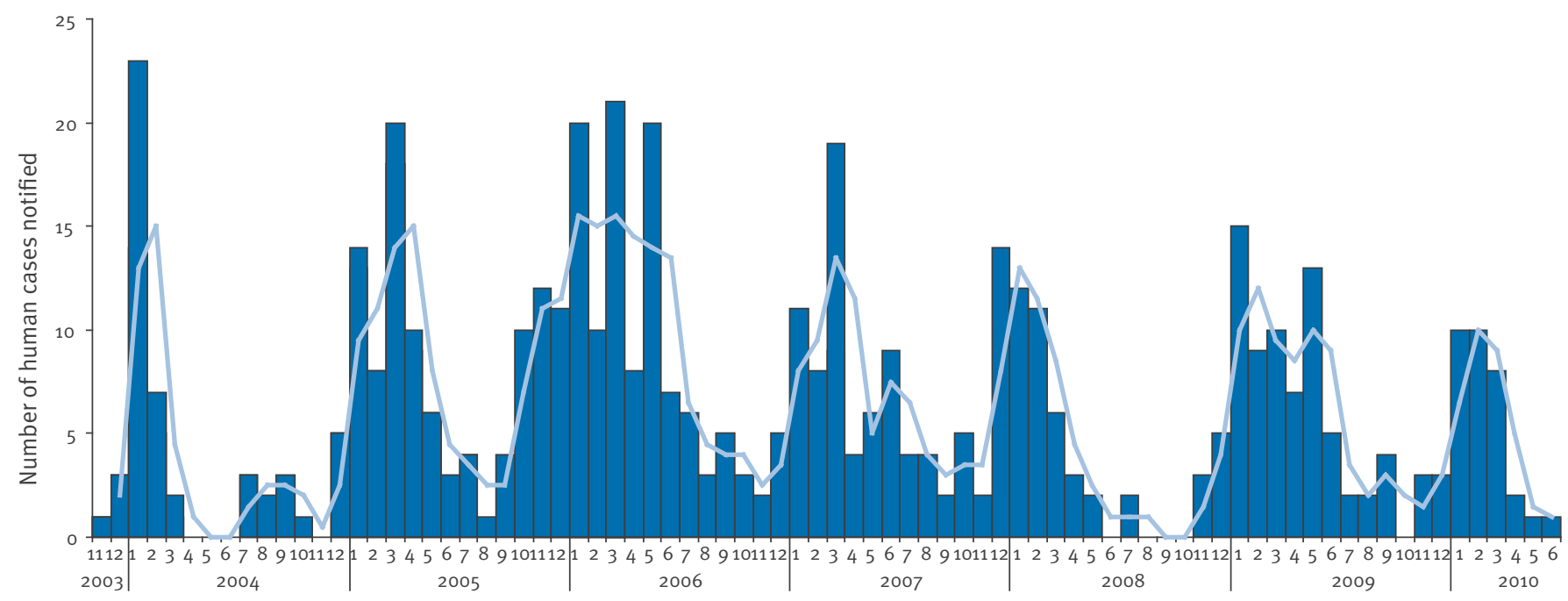

Year and month

Source: Data collected by the epidemic intelligence team at Institut de Veille Sanitaire from postings on the websites of the World Health Organization and other authoritative national sources in the 15 countries. 


\section{TABLE 2}

Human A(H5N1) influenza cases and deaths notified to the World Health Organization, 1 November 2003-1 July 2010, by world zone and date of symptom onset $(n=500)$

\begin{tabular}{|c|c|c|c|c|c|c|c|}
\hline & $\begin{array}{l}\text { Nov 2003- } \\
\text { Dec } 2005\end{array}$ & 2006 & 2007 & 2008 & 2009 & To 1 July 2010 & \\
\hline $\begin{array}{l}\text { Number of cases by world } \\
\text { zone }^{a}\end{array}$ & & & & & & & Total \\
\hline Africa & 0 & 1 & 1 & 0 & 0 & 0 & 2 \\
\hline Asia & 148 & 73 & 62 & 36 & 34 & 13 & 366 \\
\hline Near East & 0 & 41 & 25 & 8 & 39 & 19 & 132 \\
\hline World total cases & 148 & 115 & 88 & 44 & 73 & 32 & 500 \\
\hline $\begin{array}{l}\text { Proportion of world cases for } \\
\text { selected countries }\end{array}$ & & & & & & & Average \\
\hline Indonesia & $14 \%$ & $48 \%$ & $48 \%$ & $55 \%$ & $29 \%$ & $13 \%$ & $33 \%$ \\
\hline Vietnam & $63 \%$ & $0 \%$ & $9 \%$ & $14 \%$ & $7 \%$ & $22 \%$ & $24 \%$ \\
\hline Egypt & $0 \%$ & $16 \%$ & $28 \%$ & $18 \%$ & $53 \%$ & $59 \%$ & $22 \%$ \\
\hline $\mathrm{N}$ deaths by world zone $\mathrm{e}^{\mathrm{a}}$ & & & & & & & Total \\
\hline Africa & 0 & 0 & 1 & 0 & 0 & 0 & 1 \\
\hline Asia & 79 & 58 & 49 & 29 & 28 & 7 & 250 \\
\hline Near East & 0 & 21 & 9 & 4 & 4 & 7 & 45 \\
\hline World total deaths & 79 & 79 & 59 & 33 & 32 & 14 & 296 \\
\hline $\begin{array}{l}\text { Case-fatality rates in selected } \\
\text { countries (\%) }\end{array}$ & & & & & & & Average \\
\hline Indonesia & $65 \%$ & $82 \%$ & $88 \%$ & $83 \%$ & $90 \%$ & $75 \%$ & $83 \%$ \\
\hline Vietnam & $45 \%$ & NA & $63 \%$ & $83 \%$ & $100 \%$ & $29 \%$ & $50 \%$ \\
\hline Egypt & NA & $56 \%$ & $36 \%$ & $50 \%$ & $10 \%$ & $37 \%$ & $31 \%$ \\
\hline
\end{tabular}

NA: Not applicable.

a Africa: Djibouti, Nigeria; Asia: Bangladesh, Cambodia, China, Indonesia, Laos, Myanmar, Pakistan, Thailand, Vietnam; Near East: Azerbaijan, Egypt, Iraq, Turkey.

Source: Data collected by the epidemic intelligence team at Institut de Veille Sanitaire from postings on the websites of the World Health Organization and other authoritative national sources in the 15 countries.

\section{FIGURE 2}

A(H5N1) avian influenza in animals and humans (by date of onset) in affected countries, 1 January-1 July 2010

Mediterranean and Central European area

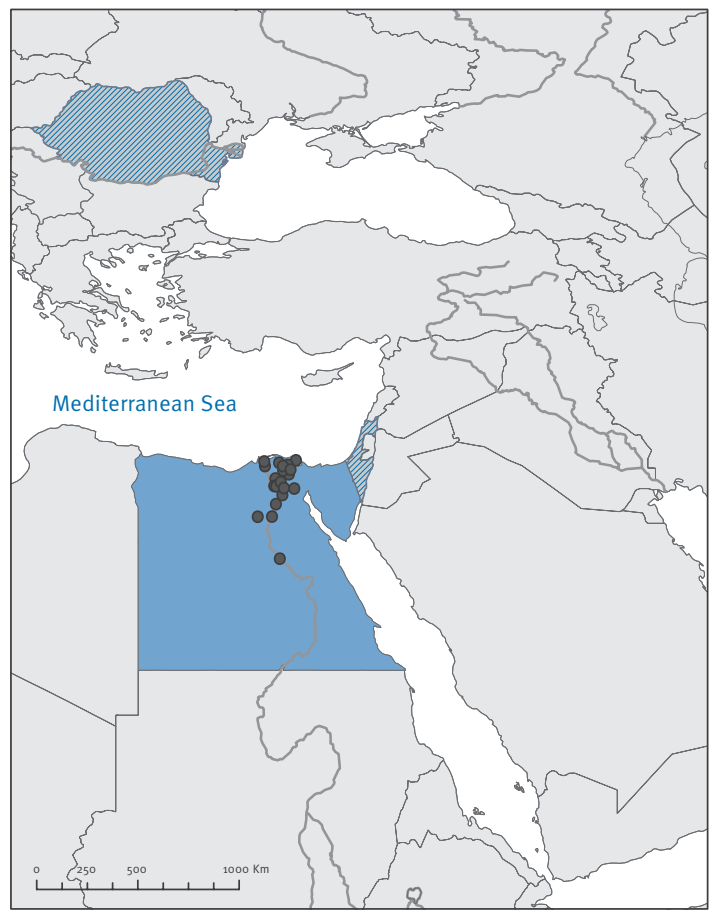

- 1 confirmed and notified human case of $\mathrm{A}\left(\mathrm{H}_{5} \mathrm{~N}_{1}\right)$ influenza

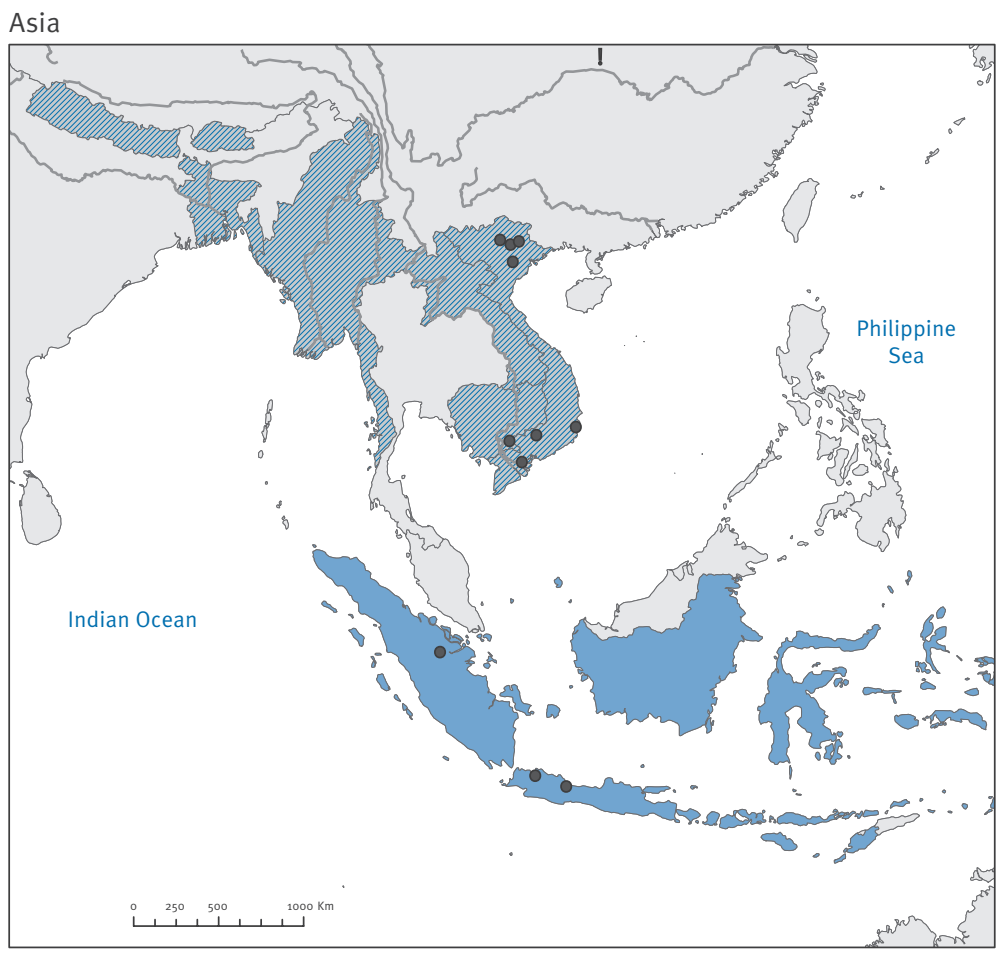

$\square$ No reported outbreak

Avian outbreaks moradic outbreaks reported (poultry flocks and farms) $\square$ Enzootic

Source: Data collected by the epidemic intelligence team at Institut de Veille Sanitaire from postings on the websites of the World Health Organization and other authoritative national sources in the 15 countries. 
Asia, notably in Indonesia, China and Vietnam (Table 1). Since the start of the epidemic, Indonesia remains the most affected country (33\% of cases and $46 \%$ of deaths notified worldwide). Indonesia notified 21 cases including 19 deaths (CFR 90\%) in 2009 and four cases including three deaths (CFR 75\%) in 2010 up to 1 July.

The number of cases has fallen in Asia while it has progressively increased in the Near East (Azerbaijan, Egypt, Iraq and Turkey). Between November 2003 and December $2005,100 \%$ of notified cases occurred in Asia (Table 2). In 2006 and 2007, the annual proportion of cases notified by Asian countries remained somewhat stable at $63 \%$ and $70 \%$, respectively. From January 2008 to 1 July 2010, 83 (56\%) of 149 notified cases occurred in Asia, the remaining 66 cases worldwide were notified by Egypt (Tables 1 and 2). The percentage of cases notified by Egypt has risen steadily from $18 \%$ of worldwide cases in 2008 , to $53 \%$ in 2009 , to $59 \%$ of worldwide cases notified to date for 2010 .

Changes in the $\mathrm{H}_{5}$ haemagglutinin have determined a phylogeny with clades and sub-clades. Clade 2.2.1 viruses circulate in poultry in Egypt while clade 2.3.2 and 2.3.4 viruses circulate in Asia [7]. There is no conclusive evidence for differences in virulence or resistance to oseltamivir among these viruses. The health outcomes for humans infected with these viruses can be explained by differences in the timeliness and type of medical management and drug treatment.

The overwhelming majority of cases with documented exposure acquired the influenza $A\left(\mathrm{H}_{5} \mathrm{~N}_{1}\right)$ virus from sick or dead poultry or wild birds. Many cases lack documented exposure while for some, although this was never definitively proven, there is a strong suspicion of involving environmental sources or human-to-human transmission.

\section{Clustered cases and human- \\ to-human transmission}

Since 2003, there have been at least 40 clustered events involving a total of over 100 confirmed cases in 12 countries: Azerbaijan, Cambodia, China, Egypt, Indonesia, Iraq, Laos, Nigeria, Pakistan, Thailand, Turkey and Vietnam. Overwhelmingly, the suspected or documented source was common exposure to sick or dead poultry, although investigation concluded that limited human-to-human transmission occurred in some instances: Most of these clusters involved persons with close familial ties [8]. Although its relevance remains debated [9], at least some degree of genetic susceptibility probably plays a role, as shown by events such as the three-generation transmission cluster described in 2006 in the Karo district [10] or the family clusters described in Turkey [11]. These clusters of limited human-to-human transmission occurred after people had close and repeated contact with cases and did not fully observe standard precautions to prevent infection [12]. Cases of nosocomial influenza $\mathrm{A}\left(\mathrm{H}_{5} \mathrm{~N}_{1}\right)$ transmission had been described in Hong Kong hospitals in 1997 [13]. Since 2003, however, no confirmed influenza $\mathrm{A}\left(\mathrm{H}_{5} \mathrm{~N}_{1}\right)$ transmission in the healthcare setting has been documented in studies done to date [14].

\section{Quality of available information}

Human case detection and reporting largely depends on the availability and intensity of reliable diagnostic efforts. The global influenza $A\left(\mathrm{H}_{5} \mathrm{~N}_{1}\right)$ case count probably vastly underrepresents the true case burden worldwide. Since December 2009, Indonesian health authorities have resumed their collaboration with WHO and notify cases officially. Since January 2009, 25 cases and 22 deaths (CFR 88\%) have been notified from the Indonesian archipelago. With the exception of a single case documented in Riau Province (central Sumatra), all notified cases lived on the island of Java. This geographical distribution and the comparatively high CFR suggests that access to diagnosis may be uneven, that severe cases are overrepresented among detected cases and/or that timely clinical management remains a challenge. In China, human cases continue to be reported with no prior notification of influenza $\mathrm{A}\left(\mathrm{H}_{5} \mathrm{~N}_{1}\right)$ circulation in poultry, pointing to the probable underdetection or underreporting of poultry outbreaks in that country. In an area such as upper Egypt, access to timely diagnosis and care is associated with lower CFR, but suspected human cases occurring in remote locations may not all be officially detected and/or reported and would have contributed to a higher CFR.

\section{Conclusions}

All these elements seem to converge and sketch out the following situation: some countries which were heavily affected before 2007 (such as Thailand and Turkey) seem to have controlled the situation and reduced risks to humans. The influenza $A\left(\mathrm{H}_{5} \mathrm{~N}_{1}\right)$ virus, however, continues to circulate in poultry elsewhere, especially in Bangladesh, Egypt and Indonesia where the enzootic remains intense. The $A\left(\mathrm{H}_{5} \mathrm{~N}_{1}\right)$ influenza virus is one of several which could hypothetically give rise to a pandemic in the future [15]. Although this risk cannot be quantified, poultry outbreaks and human cases now, in contrast to the period from 2003 to 2004 , occur in some of the most densely populated urban or suburban areas in the world. Not only might this increase the risk of the virus being transmitted to humans living in close proximity to animals, it may also challenge usual control measures (which are easier to apply to large farms than for instance backyard flocks) and make it more difficult to contain a nascent influenza $A\left(\mathrm{H}_{5} \mathrm{~N}_{1}\right)$ pandemic should one arise [16].

Human cases continue and will continue to occur as long as the situation in animals is not brought under control. Authorities and populations face a complex situation in Egypt and Indonesia, but communication in these countries is transparent and constructive and allows for quick reporting of cases, especially if suspected clusters should arise. Although the global CFR reported in 2009 was lower than that observed in 2008 , 
it varies greatly between countries. Some countries report a greater number of cases and fewer deaths, perhaps due to improved surveillance and access to diagnostic techniques and medical care $[17,18]$. However, cases occurring in remote locations with no access to healthcare, although having a higher CFR, may still not come to the attention of health authorities or be reported for lack of biological confirmation.

Many clustered events have occurred, some of which are highly likely to have involved human-to-human transmission. To date, this has remained limited with no sustained community transmission. Available data, especially those gathered following clustered events, show that so far the virus shows no sign of 'humanisation', i.e. the ability to transmit easily from human to human. The overall worldwide situation of influenza $\mathrm{A}\left(\mathrm{H}_{5} \mathrm{~N}_{1}\right)$, however, has not markedly improved since 2003. This fact, and regular reintroduction of the virus by wild birds in countries where foci have been controlled (such as Bulgaria, Romania, Turkey or Vietnam) underscore the importance of maintaining adequate surveillance and response capacities for infections in both animals and humans.

The Epidemic Intelligence team at InVS's International and Tropica Department as of 1 January 2010 in alphabetical order:

Fatima Aït el-Belghiti, Philippe Barboza, Laurence Chérié-Challine, Sandra Cohuet, Dominique Dejour-Salamanca, Nathalie El Omeiri, Marc Gastellu-Etchegorry, Violaine Gauthier, Myriam Gharbi, Sophie Ioos, Guy La Ruche, Arnaud Tarantola, Laëtitia Vaillant.

\section{References}

1. Rotureau B, Barboza P, Tarantola A, Paquet C. International epidemic intelligence at the Institut de Veille Sanitaire, France. Emerg Infect Dis. 2007;13(10):1590-2.

2. World Health Organization (WHO). Avian influenza - situation in Indonesia - update. Disease outbreak news. Geneva: WHO; 5 July 2010. Available from: http://www.who.int/csr/ don/2010_07_05/en/index.html

3. World Organization for Animal Health (OIE). Facts and Figures: Avian Influenza. $\mathrm{H}_{5} \mathrm{~N}_{1}$ notified in 2003-2010. Paris: OIE. [Accessed July 2010]. Available from: http://www.oie.int/eng/ info ev/en Al factoids 2.htm.

4. World Health Organization (WHO). Cumulative number of confirmed human cases of avian influenza $A /\left(\mathrm{H}_{5} \mathrm{~N}_{1}\right)$ reported to WHO. Geneva: WHO; 5 July 2010. Available from: http:// www.who.int/csr/disease/avian_influenza/country/cases_ table_2010_07_05/en/index.html

5. Park AW, Glass K. Dynamic patterns of avian and human influenza in east and southeast Asia. Lancet Infect Dis. 2007;7(8):543-8.

6. Ben Jebara K. World Organization for Animal Health (OIE) report on animal health status world-wide in 2009. 78th General Session of the World Assembly of OIE Delegates. Paris: OIE; in press 2010.

7. Antigenic and genetic characteristics of influenza $A\left(\mathrm{H}_{5} \mathrm{~N}_{1}\right)$ and influenza $A\left(\mathrm{H}_{9} \mathrm{~N}_{2}\right)$ viruses and candidate vaccine viruses developed for potential use in human vaccines - February 2010. Wkly Epidemiol Rec. 2010;85(11):100-7.

8. Kandun IN, Wibisono H, Sedyaningsih ER, Yusharmen, Hadisoedarsuno W, Purba W, et al. Three Indonesian clusters of $\mathrm{H}_{5} \mathrm{~N}_{1}$ virus infection in 2005. N Engl J Med. 2006;355(21):2186-94.

9. Pitzer VE, Olsen SJ, Bergstrom CT, Dowell SF, Lipsitch M. Little evidence for genetic susceptibility to influenza $A\left(\mathrm{H}_{5} \mathrm{~N}_{1}\right)$ from family clustering data. Emerg Infect Dis. 2007;13(7):1074-6.

10. World Health Organization (WHO). Avian influenza - situation in Indonesia - update 16. Disease outbreak news. Geneva: WHO; 31 May 2006. Available from: http://www.who.int/csr/ don/2006_05_31/en/index.html
11. Human cases of influenza $\mathrm{A}\left(\mathrm{H}_{5} \mathrm{~N}_{1}\right)$ infection in eastern Turkey, December 2005-January 2006. Wkly Epidemiol Rec. 2006;81(43):410-6.

12. Influenza team (ECDC). Outbreaks of highly pathogenic avian influenza $\left(\mathrm{A} / \mathrm{H}_{5} \mathrm{~N}_{1}\right)$ in commercial poultry in Hungary and the UK--public health implications? Euro Surveill. 2007;12(7):pii=3141. Available from: http://www. eurosurveillance.org/ViewArticle.aspx?Articleld=3141

13. Buxton Bridges C, Katz JM, Seto WH, Chan PK, Tsang D, Ho W, et al. Risk of influenza $A\left(\mathrm{H}_{5} \mathrm{~N}_{1}\right)$ infection among health care workers exposed to patients with influenza A ( $\left.{ }_{5} \mathrm{~N}_{1}\right)$, Hong Kong. J Infect Dis. 2000;181(1):344-8.

14. Beigel JH, Farrar J, Han AM, Hayden FG, Hyer R, de Jong MD, et al. Avian influenza $\mathrm{A}\left(\mathrm{H}_{5} \mathrm{~N} 1\right)$ infection in humans. N Engl J Med. 2005;353(13):1374-85.

15. Peiris JS, de Jong MD, Guan Y. Avian influenza virus $\left(\mathrm{H}_{5} \mathrm{~N}_{1}\right)$ : a threat to human health. Clin Microbiol Rev. 2007;20(2):243-67.

16. Ferguson NM, Cummings DA, Cauchemez S, Fraser C, Riley S, Meeyai A, et al. Strategies for containing an emerging influenza pandemic in Southeast Asia. Nature. 2005;437(7056):209-14.

17. Sahin HA, Deveci A. Hospital experience of an avian influenza A ( $\left.{ }_{5} \mathrm{~N}_{1}\right)$ outbreak in Turkey. J Int Med Res. 2009;37(5):1501-7.

18. Kandeel A, Manoncourt S, Abd el Kareem E, Mohamed Ahmed AN, El-Refaie S, Essmat $\mathrm{H}$, et al. Zoonotic transmission of avian influenza virus (H5N1), Egypt, 2006-2009. Emerg Infect Dis. 2010;16(7):1101-7. 